\title{
Differential Expression of AMPA Receptor Subunits in NOS- Positive Neurons of Cortex, Striatum, and Hippocampus
}

\author{
Maria Vincenza Catanla, ${ }^{1}$ Thomas R. Tölle, $^{2}$ and Hannah Monyer ${ }^{1}$ \\ 'Zentrum für Molekulare Biologie (ZMBH), Universität Heidelberg, D-69120 Heidelberg, Germany, and ${ }^{2}$ Max-Planck \\ Institut für Psychiatrie, Klinisches Institut, Klinische Neuropharmakologie, D-80804 München, Germany
}

\begin{abstract}
AMPA receptor (AMPAR) subunits expression was studied in nitric oxide synthase (NOS)-positive neurons of the adult rat cortex, striatum, and hippocampus, by a double-labeling approach, combining nonradioactive in situ hybridization and immunocytochemistry. The majority of cortical and hippocampal NOS-immunopositive neurons were characterized by a predominant expression of GluR-A and -D mRNA and low or undetectable expression of GluR-B and -C mRNA. In the striatum, the expression profile of AMPAR subunits in NOS-positive neurons differed from that in the other two regions. This is reflected in the overall low expression of all AMPA receptor subunits and the paucity of GluR-D subunit expression that contrasts with the high expression of this subunit in NOS-positive cells in the hippocampus. Double-labeling experiments revealed a substantial correspondence between mRNA and protein levels of AMPAR subunits. Further evidence for the regional diversity of NOS-positive neurons is derived from the expression analysis of glutamate decarboxylase (GAD)-65 and -67 mRNAs. NOS-positive neurons expressed high levels of GAD-65, but not -67 in the cortex, high levels of both forms in the hippocampus, and low or undetectable levels of both mRNAs in the striatum. Despite of these differences, NOS-positive neurons share the common feature of low GluR-B subunit expression, suggesting the presence of AMPAR channels with high $\mathrm{Ca}^{2+}$ permeability, regardless of the regional location. The relative resistance of NOS-positive interneurons in neurodegenerative diseases suggests that glutamate receptor-mediated $\mathrm{Ca}^{2+}$ influx alone does not suffice to explain neuronal vulnerability, and additional factors have thus to be considered.
\end{abstract}

[Key words: AMPA receptor subunit, nitric oxide synthase (NOS), glutamate decarboxylase (GAD), digoxigenin, immunohistochemistry, GluRs, mRNA, nonradioactive in situ hybridization]

\footnotetext{
Received May 10, 1995; revised July 7, 1995; accepted July 10, 1995.

We thank Dr. P. H. Seeburg for interesting discussions, help with DNA constructs for cRNA prohes, and for DNA sequencing; Dr. T. Dawson, Departmen of Neuroscience, The John Hopkins University and Dr. R. J. Wenthold, Laboratory of Neurochemistry, National Institute of Health, for generously providing the brain-specific NOS antibody and the GluR-A, -B/C, and GluR-D antibodies, respectively; Dr. C. Racca for excellent assistance and advice; Dr. H. Barthelmes for statistical analysis; and Drs. P. Jonas and P. H. Seeburg for critically reading the manuscript. This research was supported by Deutsche Forschungsgemeinschaft Grant Mo 432/2-1 to H.M. and SFB 317/B9 to P. H. Seeburg.

Correspondence should be addressed to Dr. Hannah Monyer, Zentrum für Molekulare Biologie (ZMBH), Universität Heidelberg, Im Neuenheimer Feld 282, 69120 Heidelberg, Germany.

Copyright $(1995$ Society for Neuroscience $0270-6474 / 95 / 157046-16 \$ 05.00 / 0$
}

Fast excitatory transmission is mediated by $\alpha$-amino-3-hydroxy5-methyl-4-isoxazole propionic acid (AMPA)-type glutamate receptor channels (AMPARs), which are formed by a combinatorial assembly of four subunits, termed GluR-A to -D or GluR 1 to GluR4 (for review, see Hollman and Heinemann, 1994). Functional studies in recombinantly expressed receptor channels indicate that the GluR-B subunit is responsible for the low $\mathrm{Ca}^{2+}$ permeability of AMPARs (Hume et al., 1991; Burnashev et al., 1992). Although the majority of neuronal cell types investigated electrophysiologically express AMPARs that are weakly permeable to $\mathrm{Ca}^{2+}$ (Mayer et al., 1987), several neuronal cell types with highly $\mathrm{Ca}^{2+}$ permeable AMPARs have been recently identified (Iino et al., 1990; Gilbertson et al., 1991; McBain and Dingledine, 1993; Bochet et al., 1994; Jonas et al., 1994; Koh et al., 1995). Attempts to correlate the electrophysiological properties of native AMPARs and the expression of different AMPAR subunits in single identified neurons suggest that differences in the relative abundance of GluR-B mRNA underlie differences in $\mathrm{Ca}^{2+}$ permeability of native AMPARs (Bochet et al., 1994; Jonas et al., 1994).

$\mathrm{Ca}^{2+}$ influx seems to be a major factor for excitatory amino acid-induced neuronal toxicity (Choi, 1988). Both NMDA and AMPA/kainate selective receptor agonists induce cell death, but, depending on the experimental paradigm, different patterns of cell loss have been reported (Meldrum and Garthwaite, 1990; Choi, 1994). A population of neurons that exhibits a differential susceptibility to different excitotoxic agonists is represented by the nitric oxide synthase (NOS)-positive cells. These neurons have been traditionally identified by staining for dihydronicotinamide adenine dinucleotide phosphate (NADPH)-diaphorase activity. In the cortex, striatum, and hippocampus, these cells represent a small population of scattered aspiny interneurons that contain a $\mathrm{Ca}^{2+}$ /calmodulin-dependent constitutive NOS (Bredt et al., 1991a). NOS positive neurons have been shown both in vitro as well in vivo to be more susceptible to AMPA/kainate- than to NMDA-induced excitotoxicity, whereas the majority of neurons exhibit the opposite agonist sensitivity (Koh and Choi, 1988; Beal et al., 1991). Recently, it has been shown that AMPA/kainate receptor-mediated damage to NADPH-diaphorase-positive cultured neurons is dependent on extracellular $\mathrm{Ca}^{2+}$ (Weiss et al., 1994). Thus, the question arose whether these cells carry $\mathrm{Ca}^{2+}$ permeable AMPARs due to the lack of GluR-B subunit expression. Therefore, we studied the expression of $A M-$ PAR subunit mRNAs in cortical, striatal, and hippocampal NOSpositive neurons of adult rat brain with an in situ hybridizationimmunocytochemistry double-labeling technique. Considering the GABAergic nature of these NOS-positive neurons (Hedlich 
et al., 1990; Kubota et al., 1993; Valtschanoff et al., 1993a,b), we examined in addition the expression of GAD-65 and -67 isoforms in this cell population. Our results indicate that AMPARs on NOS-positive neurons contain low or undetectable amounts of the GluR-B subunit, independently of the region examined. A region-dependent variability found in the expression of the GluR-A and -D subunits as well as in the expression of the GAD isoforms suggests different functional roles of these interneurons within distinct circuits.

\section{Materials and Methods}

\section{In situ hybridization}

Antisense cRNAs synthesis. In situ hybridization histochemistry was performed with antisense cRNAs for the AMPAR subunits, NOS, NMDA receptor subunit NR1, GAD-65, and GAD-67. The DNA templates for RNA synthesis were derived from the cloned rat cDNA sequences as follows: for GluR-A, a fragment of 507 base pairs (bp) comprising 198 nucleotides of the $5^{\prime}$ untranslated region and the first 309 nucleotides (ApaI site) of the open reading frame; for GluR-B, a 368 bp EcoRI fragment of residues 2583-2951 (nucleotide residues numbered from the first residue of the initiation ATG codon); for GluRC, a fragment of 395 bp encompassing 56 nucleotides of the $5^{\prime}$ untranslated region and the first 339 nucleotides (ApaI site) of the coding sequence; for GluR-D, a 541 bp XhoI-XbaI fragment comprising 230 $\mathrm{bp}$ of the $5^{\prime}$ untraslated region and the first $311 \mathrm{bp}$ of the open reading frame; for NR1, a fragment of $1233 \mathrm{bp}$ comprising $218 \mathrm{bp}$ of the $5^{\prime}$ untranslated region and the first $1015 \mathrm{bp}$ (EcoRI site) of the open reading frame, and another $\mathrm{BglII}-\mathrm{KpnI}$ fragment of $351 \mathrm{bp}$ corresponding to residues 758-1109 of the coding sequence (Moriyushi et al., 1991). A 371 bp DNA fragment of the rat GAD-65 sequence (713-1085 nucleotide residues; Erlander et al., 1991), a 458 bp DNA fragment of the GAD-67 sequence (1-458 nucleotide residues; Wyborski et al., 1990), and a 407 bp DNA fragment of the rat brain NOS sequence (1-407 nucleotides residues; Bredt et al., 1991b) were obtained by polymerase chain reaction with rat hippocampal cDNA as a template. These fragments were subcloned into the pBluescript $\mathrm{SK}^{-}$transcription vector (Stratagene, La Jolla, CA). All recombinant plasmids were linearized and the cloned DNAs transcribed by T3 (Boehringer-Mannheim, Mannheim, Germany) or T7 (Promega, Madison, WI) polymerase. In vitro transcription was carried out in the presence of $1 \mu \mathrm{g}$ of linearized DNA, $1 \times$ transcription buffer (Boehringer-Mannheim), and a mixture of 10 mm ATP, CTP, GTP, 2 mm UTP (Pharmacia, Uppsala, Sweden ) and 8 mM digoxigenin (DIG)-11-UTP (Buehringer-Mannheim) for $2 \mathrm{hr}$ at $37^{\circ} \mathrm{C}$. The concentration of DIG-11-UTP used in this study is higher than the concentration used by others (6.5 mM UTP; 3.5 mM DIG-UTP). The efficiency of transcription was lower with our mixture; however, we obtained cRNA probes that had a higher "specific activity" and allowed us to obtain in brain sections a high signal-to-noise ratio due to the relatively short time of color development (see Hybridization and detection). After extraction and precipitation, the probe was resuspended in $50 \mu \mathrm{l}$ DEPC-treated water containing 20 units of RNAse inhibitor (Promega), and stored at $-20^{\circ} \mathrm{C}$. The concentration of each probe was checked by running an aliquot on a denaturating gel and serial dilutions of cach probe were blotted on nitrocellulose and detected with a nucleic acid detection kit (Boehringer-Mannheim). The intensity of the signal for GluR-A to GluR-D antisense probes was comparable.

Tissue preparation. Adult Sprague-Dawley rats $(150-250 \mathrm{gm})$ were anesthetized with an intraperitoneal injection of ketamine hydrochloride $(0.4 \mathrm{ml} / \mathrm{kg}$ body weight $)$ and xylazine hydrochloride $(1 \mathrm{ml} / \mathrm{kg}$ body weight), and quickly perfused through the ascending aorta with $200 \mathrm{ml}$ of $0.9 \% \mathrm{NaCl}$ in $50 \mathrm{~mm}$ sodium phosphate buffer $\mathrm{pH} 7.5$ followed by $300 \mathrm{ml}$ of freshly made fixative solution containing $4 \%$ paraformaldehyde in $10 \mathrm{~mm}$ phosphate-buffered saline $\mathrm{pH} 7.4(1 \times$ PBS $)$. Brains were removed, postfixed over night at $4^{\circ} \mathrm{C}$ in the same fixative solution, and stored in a sterile cryoprotective solution of $20 \%$ sucrose in 100 mM sodium phosphate buffer at $4^{\circ} \mathrm{C}$ until use (never more than 2 months). Although it was not the object of a systematical study, we did not observe any loss of in situ hybridization signal intensity in sections from brains stored for different lengths of time. Brain sections $(30 \mu \mathrm{m})$ were cut on a vibratome, collected in $1 \times$ PBS and immediately processed for in situ hybridization histochemistry. All solutions were made up with autoclaved, diethyl pyrocarbonate (DEPC)-treated water.

Hybridization and detection. The nonradioactive in situ hybridization method described in this study is a modification of previously described protocols (Wahle and Beckh, 1992; Esclapez et al., 1993). Free-floating sections were briefly rinsed in PBS and sequencially incubated in the following solutions: $0.2 \mathrm{M} \mathrm{HCl}$ for $10 \mathrm{~min}$; $1 \times$ PBS for $5 \mathrm{~min} ; 0.25 \%$ acetic anhydride in $1.5 \%$ triethanolamine $/ 0.3 \mathrm{M} \mathrm{NaCl}, \mathrm{pH} 8$, for $10 \mathrm{~min}$; $1 \times$ PBS for $5 \mathrm{~min} ; 0.1 \%$ Triton X-100 in PBS for $10 \mathrm{~min} ; 1 \times$ PBS for 5 min twice. Sections were then transferred into prehybridization solution: $50 \%$ formamide; $250 \mu \mathrm{g} / \mathrm{ml}$ heat-denatured and sheared salmon sperm DNA (SIGMA-Aldrich, Deisenhofen, Germany); $100 \mu \mathrm{g} / \mathrm{ml}$ yeast t-RNA (Serva, Heidelberg, Germany); $0.05 \mathrm{M}$ sodium phosphate buffer, pH 6.5; $4 \times$ SSC $(1 \times$ SSC, $150 \mathrm{~mm} \mathrm{NaCl}, 15 \mathrm{~mm}$ Na citrate, $\mathrm{pH} 7.0) ; 5 \%$ dextran sulphate; $0.02 \%$ polyvinylpirrolidone, $0.02 \%$ BSA, $0.02 \%$ Ficoll $400\left(1 \times\right.$ Denhart solution) for $1 \mathrm{hr}$ at $55^{\circ} \mathrm{C}$. Sections were then incubated for at least $12 \mathrm{hr}$ at $55^{\circ} \mathrm{C}$ in the same solution with sense or antisense cRNA probes at a final concentration of $1 \mathrm{ng} / \mu \mathrm{l}$. Sections were washed for $10 \mathrm{~min}$ in $4 \times$ SSC and treated with ribonuclease A $(50 \mu \mathrm{g} / \mathrm{ml}$ in $0.5 \mathrm{M} \mathrm{NaCl}, 1 \mathrm{~mm}$ EDTA, $10 \mathrm{~mm}$ Tris-HCl buffer, $\mathrm{pH} 8)$ for $20 \mathrm{~min}$ at $37^{\circ} \mathrm{C}$. This was followed by rinses in $2 \times \mathrm{SSC}$ for $2 \mathrm{hr}$ at room temperature, and $0.1 \times \mathrm{SSC}$ for $30 \mathrm{~min}$ at $55^{\circ} \mathrm{C}$. Sections were then washed twice $(10 \mathrm{~min}$ each) in $100 \mathrm{~mm}$ Tris- $\mathrm{HCl}$ buffer, $150 \mathrm{~mm}$ $\mathrm{NaCl} \mathrm{pH} 7.5$ (buffer 1); preincubated for $1 \mathrm{hr}$ in the same buffer containing $4 \%$ BSA, $0.25 \%$ DMSO, $1 \%$ Triton $\mathrm{X}-100$, and incubated over night at $4^{\circ} \mathrm{C}$ in the alkaline phosphatase (AP)-conjugated antibodies (FAB fragment, Boehringer-Mannheim) diluted 1:750 in buffer 1 containing $2 \% \mathrm{BSA}$ and $0.3 \%$ Triton $\mathrm{X}-100$. On the following day, the sections were washed in buffer 1 (three times $15 \mathrm{~min}$ each), in $100 \mathrm{~mm}$ Tris- $\mathrm{HCl}, 100 \mathrm{mM} \mathrm{NaCl} \mathrm{pH} 7.5$ (two times, $5 \mathrm{~min}$ each), in $100 \mathrm{~mm}$ Tris- $\mathrm{HCl}, 100 \mathrm{mM} \mathrm{NaCl}, 50 \mathrm{mM} \mathrm{MgCl}, \mathrm{pH} 9.5$ (buffer 2), and then incubated in buffer 2 containing $4.5 \mu \mathrm{l} / \mathrm{ml}$ of nitroblue tetrazolium stock solution $(75 \mathrm{mg} / \mathrm{ml}$ in $70 \%$ dimethylformamide $), 3.5 \mu 1 / \mathrm{ml}$ of X-phosphate (5-bromo-4-chloro-3-indolylphosphate, $50 \mathrm{mg} / \mathrm{ml}$ of $100 \%$ dimethylformamide) and $0.24 \mathrm{mg} / \mathrm{ml}$ of levamisole (Sigma). The chromogen reaction was stopped by rinsing the sections in $10 \mathrm{~mm}$ Tris- $\mathrm{HCl}$, $1 \mathrm{~mm}$ EDTA, $\mathrm{pH} 8$ for $15 \mathrm{~min}$ and then in $10 \mathrm{~mm}$ Tris- $\mathrm{HCl}, \mathrm{pH} 8$ (twice, $15 \mathrm{~min}$ ). Sections were either mounted on slides, air dried and coverslipped in Mowiol medium, or processed for immunohistochemistry.

Color development of slides prehybridized with the GluR-A to -D antisense cRNA probes was monitored periodically during the chromogen reaction to achieve optimal staining. Optimal staining was defined in a series of control experiments by stopping the reaction at different time points until maximal staining with a low background of tissue staining was achieved in specific neuronal types showing high levels of mRNA (hilar neurons of the hippocampus for GluR-A and -D probes; interneurons of stratum oriens for GluR-C probe and pyramidal neurons of the hippocampus for GluR-B probe). Specificity of signal was checked by examining different brain regions and comparing relative levels of staining in different cell types (see Fig. 1). The optimal color reaction was $5 \mathrm{hr}$ for the GluR-B and -C probes and $4 \mathrm{hr}$ for the GluR-A and -D probes. No specific labeling was observed following in situ hybridization with DIG-labeled sense RNA probes. No staining was observed when the DIG-labeled probes were omitted in the hybridization solution. We compared directly for each subunit the intensity of signal obtained with our DIG-labeled cRNA probes with the specific cellular labeling obtained with ${ }^{35}$ S-oligonucleotides (Keinänen et al., 1990). No apparent differences were detected. Color development of NOS, GAD-65, and -67 , and NR 1 in situ hybridization signal developed faster and gave a strong signal in less than $2 \mathrm{hr}$. For double-labeling experiments with antibodies against AMPA receptor subunits, color development of sections hybridized with the NOS-specific antisense cRNA probe was stopped after $30 \mathrm{~min}$ (for analysis in the cortex and striatum) and $2 \mathrm{hr}$ (for analysis in the hippocampus).

\section{Immunocytochemistry}

After the AP reaction was stopped, sections were immediately transferred into $50 \mathrm{~mm}$ Tris- $\mathrm{HCl}$ buffer containing $1.5 \% \mathrm{NaCl}$, pH 7.4 (TBS) and then permeabilized for $30 \mathrm{~min}$ in TBS with $0.4 \%$ Triton X-100. This was followed by a preincubation in TBS containing $0.2 \%$ Triton $\mathrm{X}-100,4 \%$ normal goat serum (NGS), and $0.02 \%$ sodium azide $\left(\mathrm{NaN}_{3}\right)$. Sections were then incubated over night at $4^{\circ} \mathrm{C}$ in primary antibodies in TBS containing $0.1 \%$ Triton $\mathrm{X}-100,2 \% \mathrm{NGS}$, and $0.02 \% \mathrm{NaN}_{3}$. Rat brain NOS antibody has been raised against a glutathione-S-transferase $\mathrm{N}$-terminal fusion protein of the cloned rat cerebellar NOS (amino acids 1-181) (Bredt et al., 1991b), and it is specific for the neuronal constitutive form of NOS (Dinerman et al., 1994). The NOS antibody was 

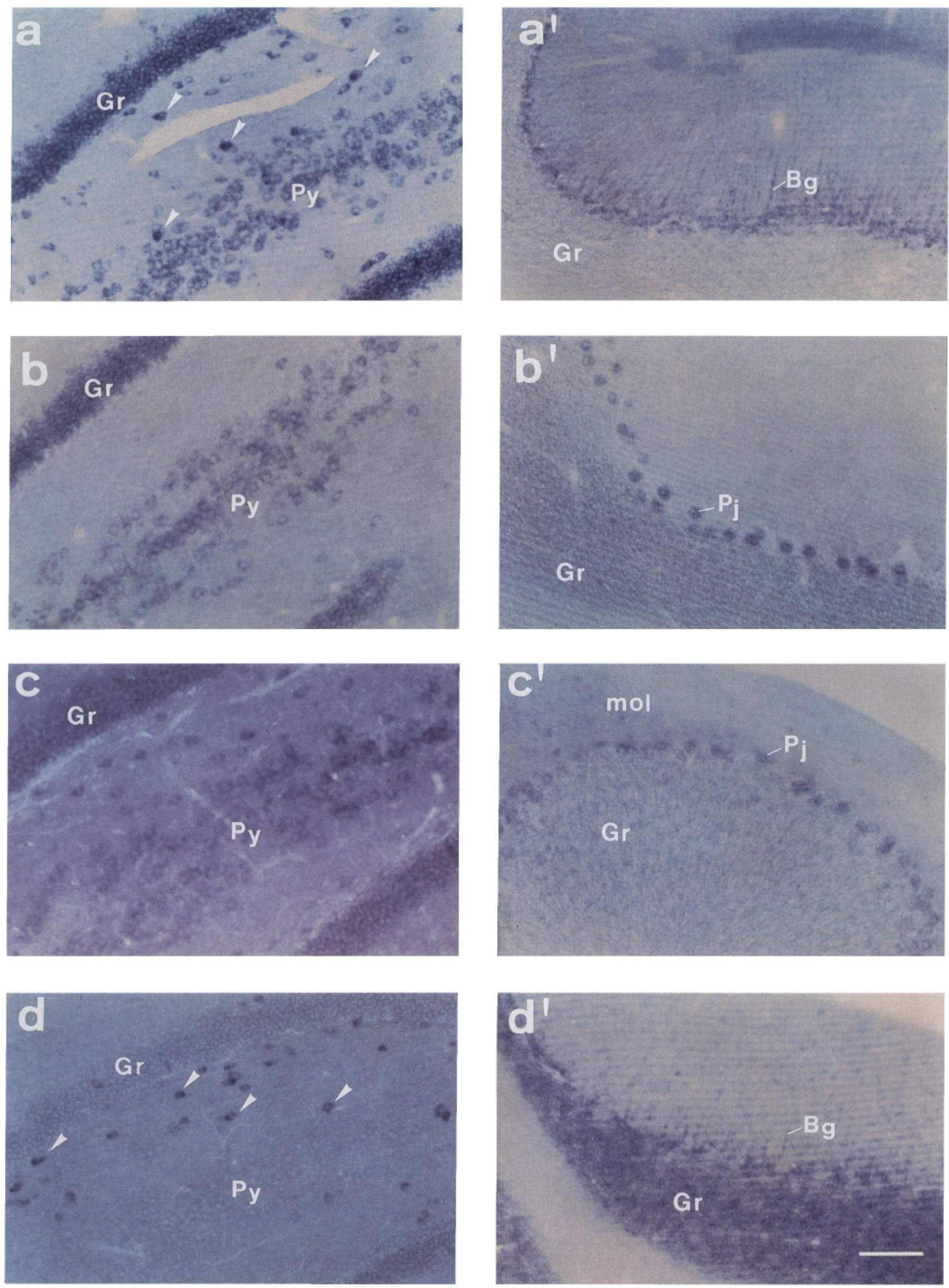
used at a dilution 1:25 (final concentration, $4 \mu \mathrm{g} / \mathrm{ml}$ ). The antibodies against AMPAR subunits were used at concentrations of $2.4 \mu \mathrm{g} / \mathrm{ml}$ for GluR-A, $2.8 \mu \mathrm{g} / \mathrm{ml}$ for GluR-B/C, and $1.2 \mu \mathrm{g} / \mathrm{ml}$ for GluR-D (Petralia and Wenthold, 1992). On the following day, sections were washed three times $\left(10 \mathrm{~min}\right.$ each wash) with cold $\left(4^{\circ} \mathrm{C}\right)$ TBS and incubated for 2.5 $\mathrm{hr}$ in goat-antirabbit IgG-carboxymethylindocyanine 3,18 (Cy3)-conjugated (1:200, at room temperature, in the dark; Jackson ImmunoResearch Laboratories-Dianova, Hamburg, Germany). Sections were then washed in TBS with 1\% NGS twice and in TBS twice (10 min each). After a brief final rinse in Tris- $\mathrm{HCl} 10 \mathrm{mM}, \mathrm{pH} 7.5$, sections were mounted on slides and coverslipped in Mowiol medium.

The in situ hybridization treatment and the deposition of formazan salts did not affect the ability of the NOS polyclonal antibody to detect the antigen. A comparable number of NOS-positive cells was detected in the striatum with the immunoperoxidase/DAB color reaction in slides not pretreated $(186 \pm 43 ; n=3)$ and with the immunofluorescent secondary antibody in slides prehybridized with the antisense GluR-A (160 $\pm 8 ; n=2)$, GluR-B $(123 \pm 20 ; n=2)$, GluR-C $(138 \pm 35 ; n=3)$, and GluR-D probes $(122 \pm 11 ; n=3)$. Immunofluorescence was detectable even when a strong in situ hybridization signal was present in the cell cytoplasm as in the case of probes for GAD65 and NR1.

\section{Histochemistry}

For demonstration of NADPH diaphorase activity, slices were incubated in $100 \mathrm{~mm}$ Tris-HCl buffer, $\mathrm{pH} 8$ containing $1.2 \mathrm{~mm} \mathrm{NADPH}$ (reduced form; Sigma), $0.25 \mathrm{~mm}$ nitroblue tetrazolium and 10\% DMSO for a variable length of time ( 30 min to a few hours) at $37^{\circ} \mathrm{C}$. When combined with GluRA, B/C, and D immunohistofluorescence, development of reaction was stopped after $30 \mathrm{~min}$ (to analyze cortical and striatal neurons) and $90 \mathrm{~min}$ (to analyze hippocampal neurons). The best results were obtaincd when NADPH diaphorase activity assay was performed after immunohistochemistry.

\section{Densitometry}

The integrated optical density (O.D.) of the AP reaction product concentrated within the cytoplasm was measurcd using the OPTIMAS
Bioscan program. NOS-positive cells were identified under epifluorescent illumination using the rhodamine filters and visualized on a videomonitor connected to the CCD videocamera Image Point C (Photometrics). 'The identical field was then observed under normal light and, combining both epifluorescent and normal illumination, each NOS-positive cell was localized using the bright-field microscopy. The in situ hybridization signal was identified as a cytoplasmic rim of the AP reaction product with sparing of the cell nucleus in most cases. Occasionally, very dark spots of AP reaction precipitate were observed within the nucleus (see Figs. 2, 4, and 7). Thus, we preferred to analyze the O.D. of the color product present only in the cytoplasm. For each field analyzed, the O.D. of background was measured in several small regions of interest (R.O.I.)) of about $20-30 \mu \mathrm{m}^{2}$ positioned in the intercellular space surrounding the cell analyzed. The integrated relative O.D. was calculated for each cell by the formula: absolute O.D. background - absolute O.D. cell/absolute O.D. background $\times 100$. In some instances, we obtained negative values because the O.D. of the cytoplasm was less than that of the surrounding background. This can be due to either unspecific color precipitate within the extracellular matrix or to occasionally considering as background a region containing other positive cells located on a different level of focus. A cell was considered positive when its integrated O.D. was more than $5 \%$ over the background. This was established from a series of parallel control experiments using sections processed identically but incubated with sense probes or without cRNA probes.

Virtually all cortical NOS-positive neurons present in a section were analyzed, and an average of 20 randomly chosen striatal cells per slice were analyzed. In the hippocampus, only NOS-positive neurons present in the stratum oriens, radiatum, and lacunosum-moleculare were included in the analysis, whereas cells in the stratum pyramidale were excluded because it was very difficult to distinguish labeling of the NOS-positive cells from that of surrounding pyramidal neurons.

\section{Results}

General distribution of $G l u R-A,-B,-C,-D$ subunit mRNAs studied by nonradioactive in situ hybridization

Nonradioactive in situ hybridization permitted a clear visualization of neurons labeled for each AMPAR mRNA. The general

Figure 1. Comparative localization of AMPA receptor mRNAs studied with nonradioactive in situ hybridization. GluR-A, -B, -C, and -D in situ hybridization patterns are shown in sequential order from the top to the bottom of the figure in the hilar region of the hippocampus (a-d) and the cerebellar cortex $\left(a^{\prime}-d^{\prime}\right), a-d$, Several hippocampal interneurons (arrowheads) express very high levels of labeling for GluR-A and -D transcripts, whereas pyramidal cells $(P y)$ exhibit moderate to strong staining for GluR-A, -B, and -C mRNAs. Granule cells $(G r)$ of the dentate gyrus show intense staining for GluR-A and -B mRNA, and moderate for GluR-C mRNA. Staining for GluR-D mRNA is absent in the pyramidal and extremely weak in the granule cells. $a^{\prime}-d^{\prime}$, Bergmann glia cell bodies and processes $(B g)$ are clearly labeled with the GluR-A and -D probe. Bergmann glial cell processes are marked through the whole molecular layer, particularly with the GluR-A probe. Purkinje cell $(P j)$ bodies are strongly labeled only with the the GluR-B and -C probe, whereas granule cells $(G r)$ are very strongly labeled with the GluR-D probe, moderately with the GluR$\mathrm{B}$, and weakly with the GluR-C probe. No apparent labeling is present in the granule cell layer with the GluR-A probe. Some cells in the molecular layer $(\mathrm{mol})$ are labeled with the GluR-C and -D probes. Scale bar: $100 \mu \mathrm{m}$

Figure 2. NOS-positive neurons in the cortex, striatum, and hippocampus express GluR-A mRNA. Representative examples of NOS/Gluk-A mRNA positive neurons in the cortex $\left(a-a^{\prime}\right)$, striatum $\left(b-b^{\prime}\right)$, stratum oriens of CA3 region $\left(c-c^{\prime}\right)$ and hilus of the hippocampus $\left(d-d^{\prime}\right)$. On the left side of the figure NOS-positive neurons are shown under UV light epifluorescence; on the right side the same microscopic field under bright light reveals GluR-A in situ hybridization. $a-a^{\prime}$, An NOS-positive neuron in the cortex exhibits a moderate GluR-A staining (arrow). The intensity of GluR-A labeling in NOS-positive neurons was never as high as in other scattered neurons (arrowhead). $b-b^{\prime}$, Example of weak GluR-A mRNA signal in NOS-positive neurons of the striatum (arrow). As in the cortex, the majority of neurons had a light to moderate in situ hybridization signal with some scattered neurons expressing a strong signal (arrowhead). The latter were never found to be NOS positive. $c-c^{\prime}$, Strong GluR-A signal in a NOS-positive neuron of the stratum oriens of the CA3 region of the hippocampus (arrows). $d-d^{\prime}$, Strong GluR-A mRNA signal in a neuron of the hilar region of the hippocampus. Note that the NOS immunofluorescent signal was very strong in cortex $(a)$ and striatum $(b)$ compared to the hippocampus $\left(c\right.$ and $d$ ). The in situ hybridization signal was weaker in the NOS-positive neurons of the cortex $\left(a^{\prime}\right)$ and striatum $\left(b^{\prime}\right)$ than in NOS-positive cells of the hippocampus $\left(c^{\prime}\right.$ and $\left.d^{\prime}\right)$. Similar results were obtained in NOS-positive neurons in the same regions with the GluR-D probe. Gr: granule cell layer; hil: hilus; or: stratum oriens; $P y$ : pyramidal cell layer. Scale bar: $20 \mu \mathrm{m}$.

Figure 3. Paucity of GluR-B mRNA in NOS-positive neurons of the cortex, striatum, and hippocampus. Representative examples of NOS/GluR-B mRNA negative neurons in the cortex $\left(a-a^{\prime}\right)$, striatum $\left(b-b^{\prime}\right)$, stratum oriens of CA3 region $\left(c-c^{\prime}\right)$, and hilus $\left(d-d^{\prime}\right)$ of the hippocampus. $a-a^{\prime}$, Absence of GluR-B in situ hybridization signal in an NOS-positive neuron in the cortex (arrow), which is surrounded by GluR-B-positive neurons (asterisks). $b-b^{\prime}$, Lack of GluR-B labeling in an NOS-positive neuron of the striatum (arrow). The majority of neurons were moderately labeled for GluR-B mRNA. $c-c^{\prime}$, Two NOS-positive ncurons in the stratum oricns (or; top-left arrow) and stratum pyramidale (Py; bottom-right arrow) of the CA3 region of the hippocampus show a very faint signal, almost undistinguishable from the surrounding background. This contrasted with strong labeling in pyramidal cells. $d-d^{\prime}$, Undetectable levels of GluR-B in situ hybridization in an NOS-positive neuron of the hilus (hil) depicted in the indicated square space. The same field shows a NOS-negative/GluR-B-positive hilar neuron (asterisk) and strong GluR-B mRNA labeling of the granule cell layer $(G r)$. Results were very similar with the GluR-C probe. rad: stratum radiatum; other abbreviations as in the legend of Figure 2. Scale bar: $20 \mu \mathrm{m}$. 

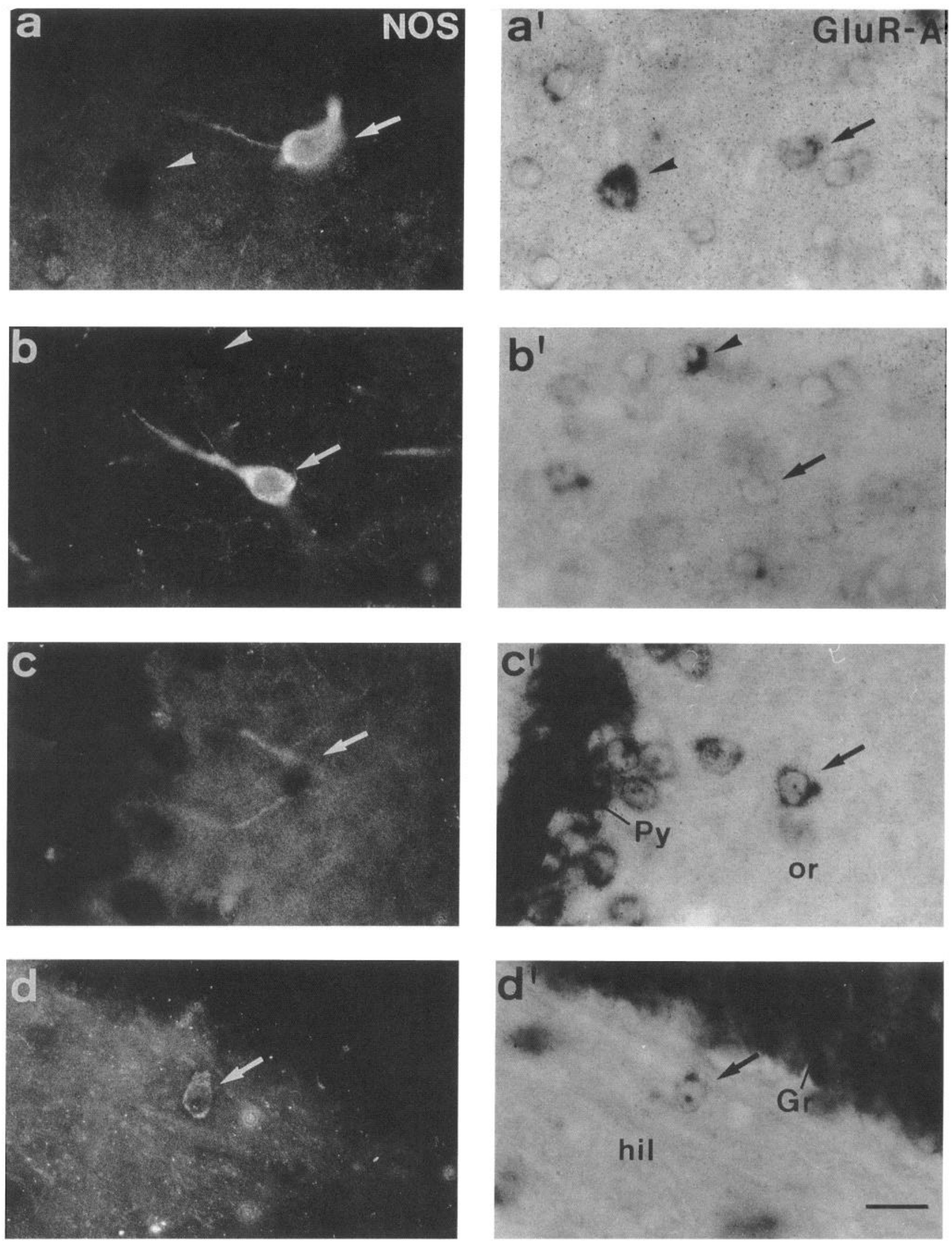

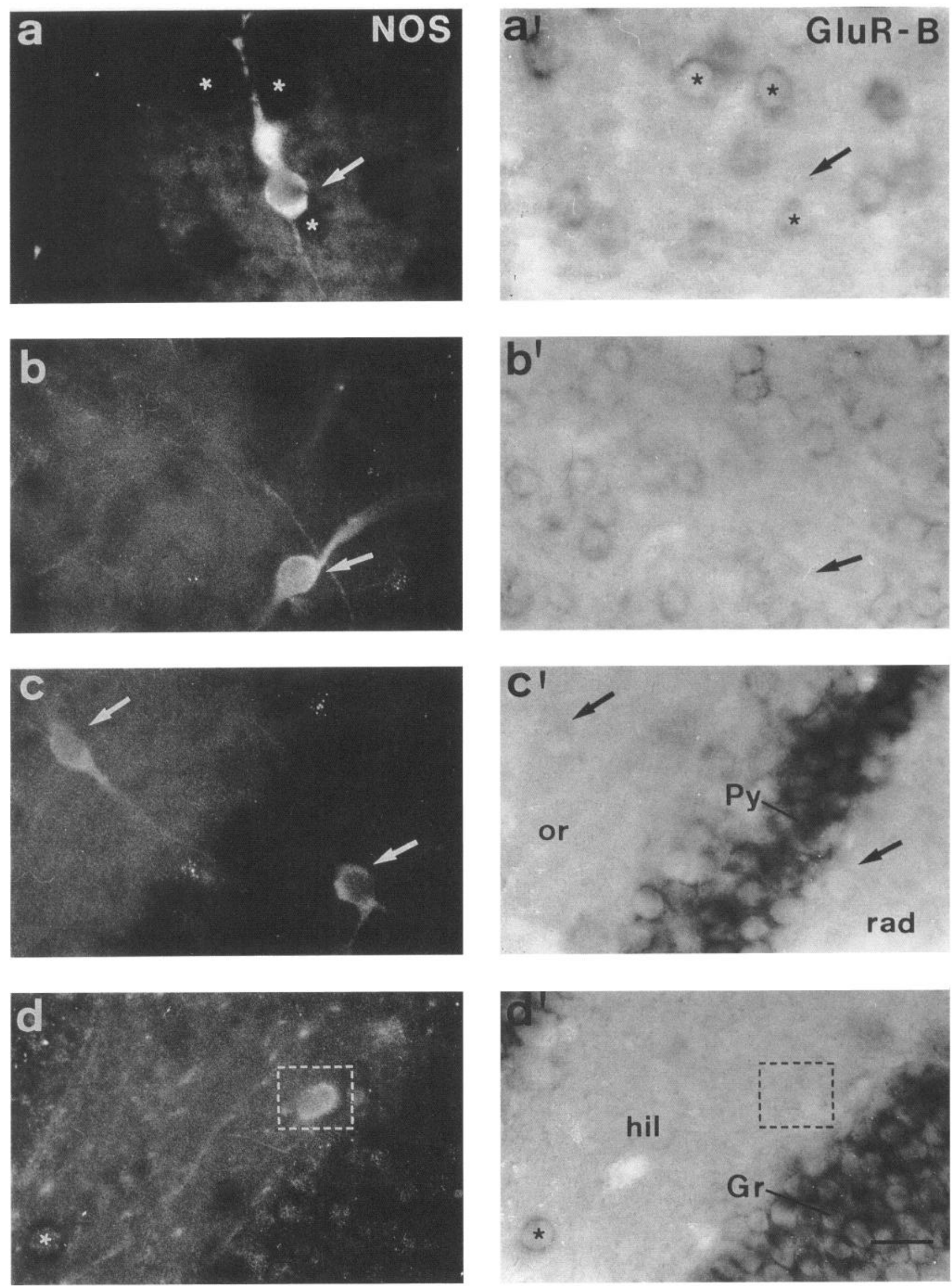
distribution of alkaline-phosphatase (AP)-labeling was identical to the distribution of AMPAR subunit mRNAs obtained with antisense ${ }^{35} \mathrm{~S}$-oligonucleotides. The cRNA probes used in this study do not distinguish between flip/flop splice variants and thus the labeling described here must be compared with the pattern of both splice variants for each subunit (Keinänen et al., 1990; Sommer et al., 1990; Sato et al., 1993).

Each probe had a specific pattern of distribution in different brain regions and, within the same section, both heavily and lightly labeled neurons were detected. The hilus of the hippocampus and the cerebellum are shown as representative examples of the differential expression of AMP $\Lambda$ R mRN $\Lambda s$ (Fig. 1). In the hippocampus, numerous putative interneurons were strongly labeled with the GluR-A and -D probes, with few cells exhibiting a very high signal for GluR-A, whereas the pyramidal cells and granule cells of the dentate gyrus were intensely stained for GluR-A, -B, and -C, but very faintly for GluR-D (Fig. 1 $a-d$ ). In the cerebellum, GluR-A and -D subunit mRNAs were strongly expressed in the Bergmann glia cell bodies and processes (Fig. $1 a^{\prime}, d^{\prime}$ ), whereas GluR-B and -C transcripts were strongly expressed in Purkinje cells (Fig. $1 b^{\prime}, c^{\prime}$ ). Cerebellar granule cells expressed GluR-B moderately and GluR-D heavily (Fig. $1 b^{\prime}, d^{\prime}$ ). In the cortex and striatum the majority of neurons were lightly labeled with the GluR-A and -D probes, whereas some scattered cells exhibited a very strong signal for GluR-A (Fig. $2 a^{\prime}, b^{\prime}$ ) and a moderate GluR-D signal; GluR-B labeling was moderate in the majority of neurons in the cortex and striatum (Fig. $3 a^{\prime}, b^{\prime}$ ); GluR-C had a laminar distribution in the cortex with all layers but layer I and IV being moderately labeled and its expression was light to moderate in the majority of striatal cells (data not shown).

\section{Combined AMPAR subunit in situ hybridization and NOS immunocytochemistry}

The distribution of NOS-positive neurons studied with fluorescent secondary antibodies was similar to that previously described with the immunoperoxidase detection method (Bredt et al., 1991a; Dinerman et al., 1994). Immunofluorescent signal was particularly strong in isolated scattered cells of the cortex and striatum and was localized in the cytoplasm and cellular processes (Figs. 2a,b, 3a,b). In the hippocampus, immunofluorescent signal was localized in scattered neurons in the strata oriens, pyramidale, radiatum, and lacunosum-moleculare, and it was much fainter than in cortical or striatal immunopositive neurons (Figs. $2 c, 3 c$ ). In the hilus several NOS-positive neurons were found to be located just below the granule cells of the dentate gyrus (Figs. $2 d, 3 d$ ).

Microscopic observation of the double-labeled slices suggested that, in the cortex, the majority of NOS-positive neurons expressed GluR-A and -D mRNAs (Fig. 2a-a'); in contrast, GluR-B and -C mRNA expression was low or undetectable (Fig. $3 a-a^{\prime}$ ). A similar subunit expression pattern was observed in the NOS-positive neurons of the hippocampus, but the GluR-A and -D in situ hybridization signal was stronger than in the cortex (Fig. $2 c-c^{\prime}, d-d^{\prime}$ ). NOS-positive neurons exhibiting a strong GluR-A and -D signal were found in all strata and in the hilus of the hippocampus. NOS-positive neurons in the striatum differed from those in cortex and hippocampus in their expression patterns of GluR mRNAs (Figs. $2 b-b^{\prime}, 3 b-b^{\prime}$ ). Microscopic inspection suggested that there is a lower proportion of NOS-positive neurons expressing the AMPAR mRNAs. GluR-A labeling was clearly detectable in several striatal NOS-containing neu- rons, but the overall levels were lower than in cortical and hippocampal NOS-positive neurons (Fig. $2 b-b^{\prime}$ ). Of particular note was the low expression of the GluR-D mRNA in the striatal NOS-positive cell population, which contrasts with the high expression of this mRNA in the hippocampal NOS-positive nellrons.

Semiquantitative analysis of the in situ hybridization signal intensity of GluR-A to -D antisense probes was performed as described in Figure 4. NOS-positive neurons in different regions of the hippocampus comprise various types of interneurons, but we limited our semiquantitative analysis to the populations of NOS-positive neurons located in the strata oriens, radiatum, and lacunosum-moleculare. The results indicated that the majority of NOS-positive neurons in cortex and hippocampus expressed GluR-A and -D mRNAs, but not GluR-B and -C mRNAs. In the striatum, about $50 \%$ of the NOS-positive cells contained GluR-A mRNA, whereas GluR-D mRNA was not found in the majority of NOS-positive neurons (Table 1). Analysis of the distribution of the integrated O.D. for each probe in the total number of cells analyzed in the three different regions confirmed our initial microscopic ohservation. NOS-positive neurons in the hippocampus expressed more GluR-A and -D mRNA than NOSpositive neurons in the cortex and striatum, whereas the signal for GluR-B and -C was low independently of the region examined. NOS-positive neurons of the striatum had lower levels of both GluR-A and -D labeling when compared to levels in cortex and hippocampus (Fig. 5). However, it appears that overall, the expression of GluR-A and -D mRNAs in NOS-positive cells is lower than in other neuronal cell types within the same region. Only few NOS-positive cells in the hippocampus expressed very high levels of GluR-A and -D mRNAs (Fig. 5).

\section{GAD-65 and -67 in situ hybridization combined with NOS immunocytochemistry}

Labcling with GAD-65 and GAD-67 antiscnsc probes showed a typical distribution for GABAergic neurons. The distinct expression profile of the two GAD isoforms has been described in previous studies (Mercugliano et al., 1992; Esclapez et al., 1993) and indicates that our probes target specifically GAD-65 or -67 mRNAs. This is exemplified in the cerebellar cortex, where GAD-65 mRNA expression was stronger in Golgi cells of the granule cell layer than in Purkinje cells, but GAD-67 mRNA expression was equally strong in both cell types (Fig. $6 a, b$ ). A striking difference between GAD-65 and GAD-67 mRNA expression was observed in the striatum. GAD-65 mRNA expression was fairly uniform with overall moderate levels of staining, whereas GAD-67 mRNA exhibited an expression variability, with moderate levels in the majority of cells and high levels in some scattered neurons (data not shown).

NOS-positive neurons exhibited a region dependent variability in the expression of the two $\mathrm{G} \Lambda \mathrm{D}$ isoforms. The most striking difference was observed in the cortex with the highest levels of GAD-65 in NOS-positive cells (Fig. $6 c, e, f$ ) and low levels of GAD-67 in this cell population (Fig. $6 d, g, h$ ). Striatal NOS-positive cells possessed comparable low levels for both GAD isoforms. In hippocampal NOS-positive cells the expression pattern of GAD-65 and -67 was similar, with variable expression levels for both probes.

Labeling of NOS-positive neurons in the striatum was always lower than in the other two regions examined with all AMPAR and GAD probes; in contrast, labeling with NR1 cRNA was equally strong in the three different areas (data not shown). The 

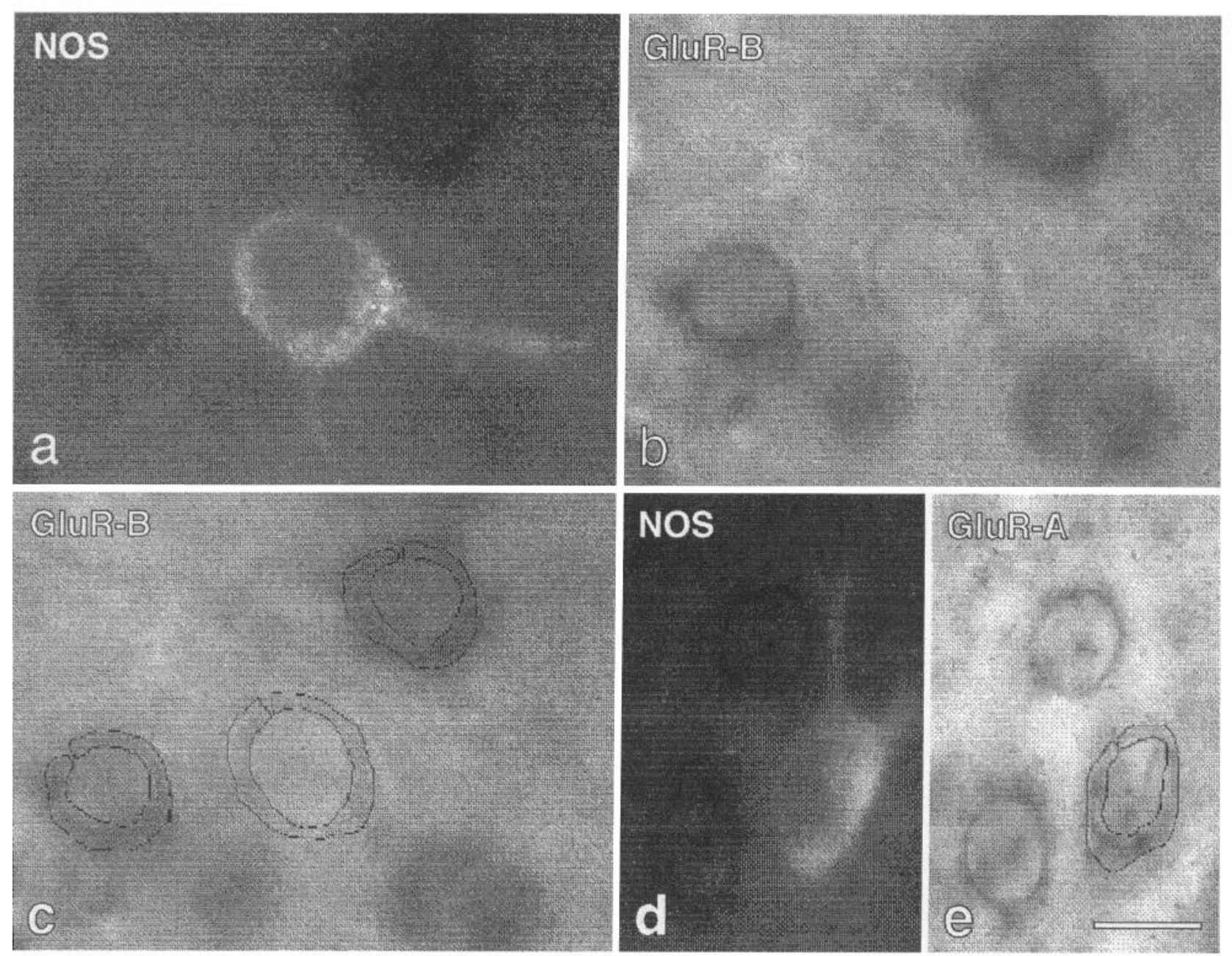

Figure 4. Example illustrating the computer-assisted image analysis of GluR in situ hybridization-NOS immunocytochemistry double-labeling. $a$, A NOS-positive cortical neuron is visualized on a video monitor connected with a CCD camera under UV light. $b$, The same field observed and digitized on the monitor under bright light reveals an underlying GluR-B in situ hybridization signal. The perinuclear area of the NOS-positive identified cell is marked by a faint color precipitate, contrasting with the other three cells that have a strong GluR-B perinuclear labeling. $c$, The same image as in $b$, showing delimitation of the cytoplasmatic area; the optical density of the perinuclear labeling was measured and normalized to the optical density of the background. Levels of O.D. of GluR-B signal were: $10 \%$ over background levels in the NOS-positive neuron (very weakly positive); $40 \%$ in the top cell; $28 \%$ in the left cell. $d-e$, NOS/GluR-A-positive neuron in the cortex; the perinuclear labeling of the NOSpositive neurons has the same intensity as neighbouring cells. Levels of O.D. of GluR-A signal were $21 \%$ over background levels in both the NOSpositive neuron and NOS-negative cell on the left. Scale bar: $10 \mu \mathrm{m}$.

latter result was confirmed with two probes of different length, suggesting that the differences observed for the GluR and GAD labeling were not due to regional differences in tissue penetration of the probes.

Table 1. AMPA receptor subunit expression in NOS positive cells in three different brain regions

\begin{tabular}{llcl} 
& Cortex & Striatum & Hippocampus \\
\hline GluR-A & $75 \%(n=133)$ & $54 \%(n=96)$ & $98 \%(n=41)$ \\
GluR-B & $32 \%(n=199)$ & $22 \%(n=112)$ & $27 \%(n=88)$ \\
GluR-C & $12 \%(n=145)$ & $9 \%(n=95)$ & $15 \%(n=95)$ \\
GluR-D & $65 \%(n=135)$ & $26 \%(n=107)$ & $92 \%(n=64)$
\end{tabular}

Values are expressed as the percentage of NOS positive neurons that were labeled by subunit specific cRNA probes. Data were collected from five slices of two brains. $n=$ total number of NOS positive neurons analyzed for each probe.

\section{Combined detection of AMPAR mRNAs and corresponding receptor proteins}

Our observation that NOS-positive neurons mainly express GluR-A and GluR-D subunit mRNAs raised the important question whether mRNA levels are reflected in the expression of the respective subunit proteins. An experiment combining GluR-A in situ hybridization and immunocytochemistry with a specific polyclonal antibody (Wenthold et al., 1992) showed a substantial concordance between mRNA and protein levels. This is particularly evident in the cortex, where scattered cells exhibiting high levels of AP reaction product showed always a strong somatic and dendritic immunoreactivity. These scattered cells are possibly interneurons, but none of them was NOS-positive (see below). The majority of cells, which showed a low level of in situ hybridization signal identifiable as a faint halo around the nucleus, had a weak somatic immunofluorescent staining that was sometimes difficult to distinguish from the surrounding stained 

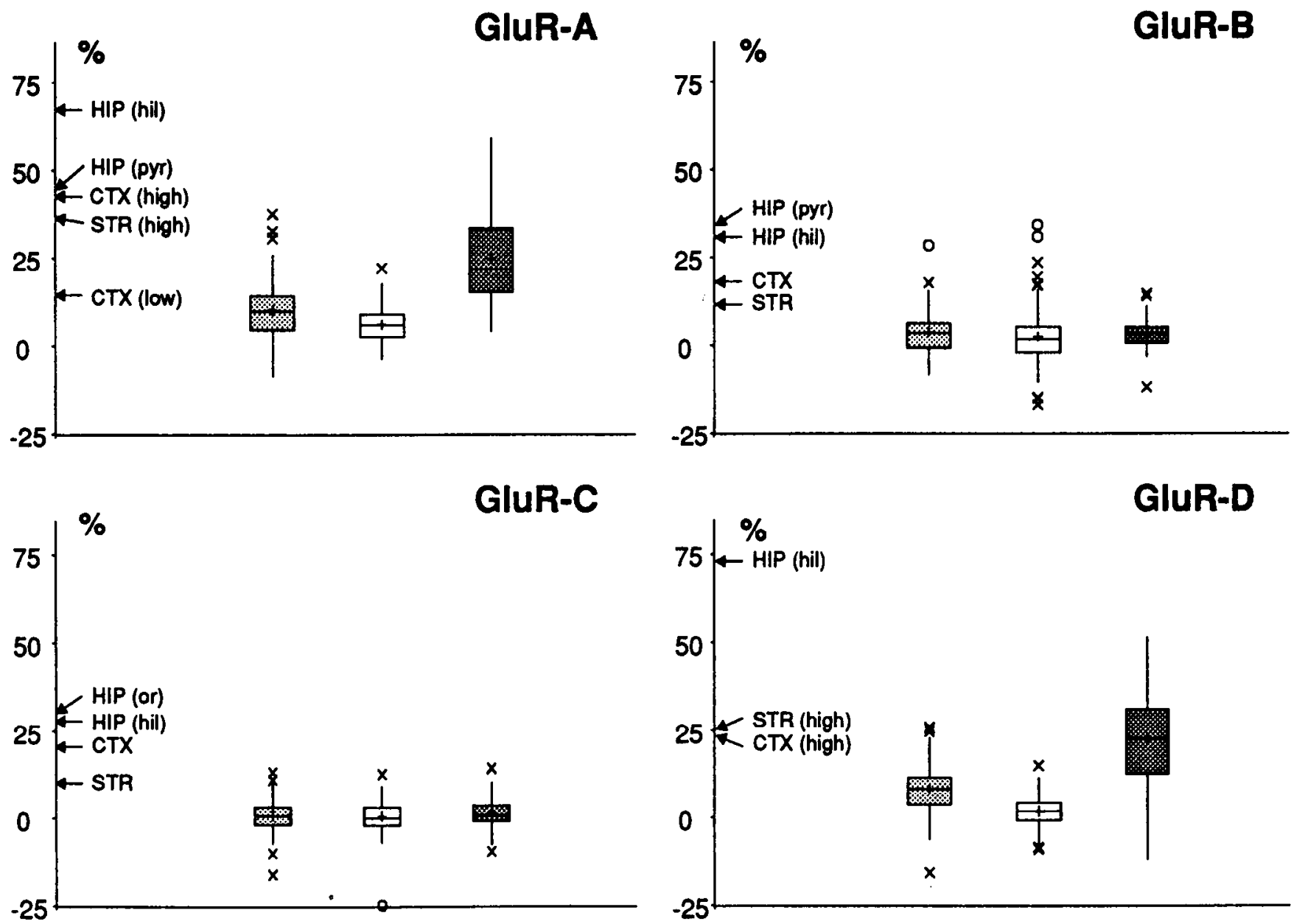

GluR-D

Cortex $\square$ Striatum Hippocampus

Figure 5. Cortical, striatal, and hippocampal NOS-positive neurons differ in the amount of GluR-A and -D mRNA expression. Quantitation of optical density (O.D.) of AP reaction product reflecting the expression of GluR-A, -B, -C, and -D mRNA in NOS-positive neurons of cortex, striatum, and hippocampus. Values are expressed in percentage (\%) of O.D. over background levels. Data were collected as indicated in Table 1. Statistical analysis revealed that the O.D. values reflecting the expression of GluR-A and GluR-D transcripts were differently distributed in the three groups of cortical, striatal, and hippocampal NOS-positive neurons (nonparametric Kruskall-Wallis test; $p<0.01$ ). The arrows on the left side of each panel indicate the average O.D. value obtained from at least five values per each slide in randomly chosen different types of NOSnegative neurons. Abbreviations: HIP (hil), hippocampal hilar neurons; $H I P$ (pyr), hippocampal pyramidal neurons; $H I P$ (or), hippocampal neurons of the stratum oriens; CTX, cortical neurons; STR, striatal neurons. For GluR-A in the cortex and striatum, two values are indicated: high corresponded to some scattered strongly labeled cells, and low corresponded to the levels present in the majority of neurons. For GluR-D, the value indicated correspond to the O.D. levels of cells that had the strongest labeling in the cortex and striatum. The boxplots are read as follows: the box contains $50 \%$ of the values, the line dividing the box represents the median, the plus sign is the mean. The lower and upper lines of the box mark the 25th and 75th percentile excluding the "outlier" values. These were divided into "near" (crosses) and "far" (circles) outliers. The former ones indicate a value that is 1.5 times the boxlength, whereas the latter ones are three times the boxlenght and more.

neuropil (Fig. $7 a-a^{\prime}$ ). Cells that had a moderate GluR-A mRNA signal exhibited always a clear immunostaining for the encoded protein (Fig. $7 b-b^{\prime}$ ). In the striatum, the neurons expressing a high level of immunofluorescence in the soma and dendrites corresponded to the scattered cells that exhibited a very strong GluR-A hybridization signal, but it was not possible to detect a clear somatic fluorescent signal in the majority of cells that were weakly labeled with the in situ probe because they appeared immersed in an intensely stained immunofluorescent neuropil. Only at the border between striatum and pallidum did a weak perinuclear in situ hybridization signal coincide with a faint immunofluorescent signal. In the hippocampus, dendrites in the stratum oriens and radiatum were more strongly immunoreactive than the cell bodies of pyramidal cells. In the stratum oriens and radiatum, it was not possible to distinguish a clear immunofluorescent signal over the somata of several interneurons that strongly expressed GluR-A mRNA, likely due to the compact dendritic immunofluorescent signal. In the hilus, where the neuropil was less intensely immunofluorescent, numerous neuronal cell bodies were both positively labeled for the antibody and the mRNA probe.

An identical experiment combining GluR-B in situ hybridization and GluR-B/C immunocytochemistry also showed a clear correspondence between mRNA and protein. The colocalization of GluR-B mRNA and protein was generally easier to evaluate than that of GluR-A due to a better defined somatic signal with this antibody. In the cortex and striatum, all the cells that had a clear, even weak, perinuclear in situ hibridization signal showed 

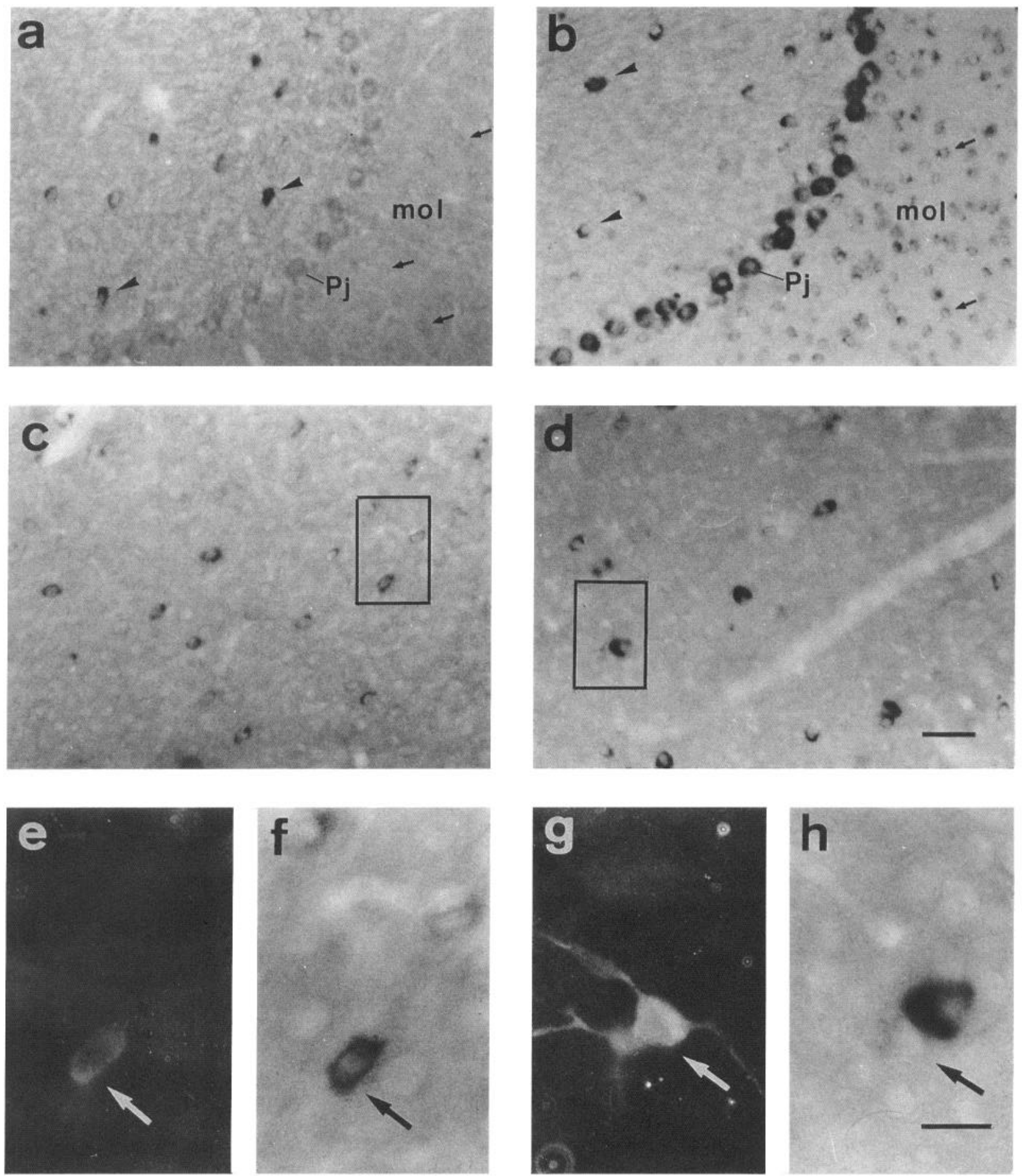

Figure 6. GAD-65 and -67 mRNAs are differentially expressed in NOS-containing neurons. $a-b$, Comparative localization of GAD-65 and-67 in the cerebellar cortex after the same time of AP reaction development. $a$, GAD-65 in situ hybridization signal is intense in putative Golgi cells (arrowheads), moderate in Purkinje ( $P j$ ), and very light in numerous cells of the molecular layer (mol; arrows). $b$, GAD-67 in situ hybridization signal is equally strong in Purkinje cells $(P j)$ and Golgi cells (arrowheads), and light to moderate in cells of the molecular layer (mol; arrows). $c$ $d$, GAD-65 and -67 mRNA distribution is similar in the cortex; rectangular spaces contain NOS-positive neurons. $c$, GAD-65 is expressed in several scattered neurons of the cortex at different levels. $d$, GAD-67 mRNA is also expressed in several neurons, but after the same time of AP reaction development, the GAD-67 signal seemed stronger than that of GAD-65 in numerous cells. $e-f$, The rectangular space depicted in $c$ contains a NOS-positive neuron (arrow) that is strongly GAD-65 mRNA positive, as revealed by UV light epifluorescence $(e)$ and bright-light illumination $(f) . g-h$, The rectangular space indicated in $d$ contains an NOS-positive neuron $(g)$, which is weakly labeled with the GAD-67 probe and is adjacent to a very strong labeled neuron $(h)$. Scale bars: $a-d, 50 \mu m ; e-h, 20 \mu m$. 

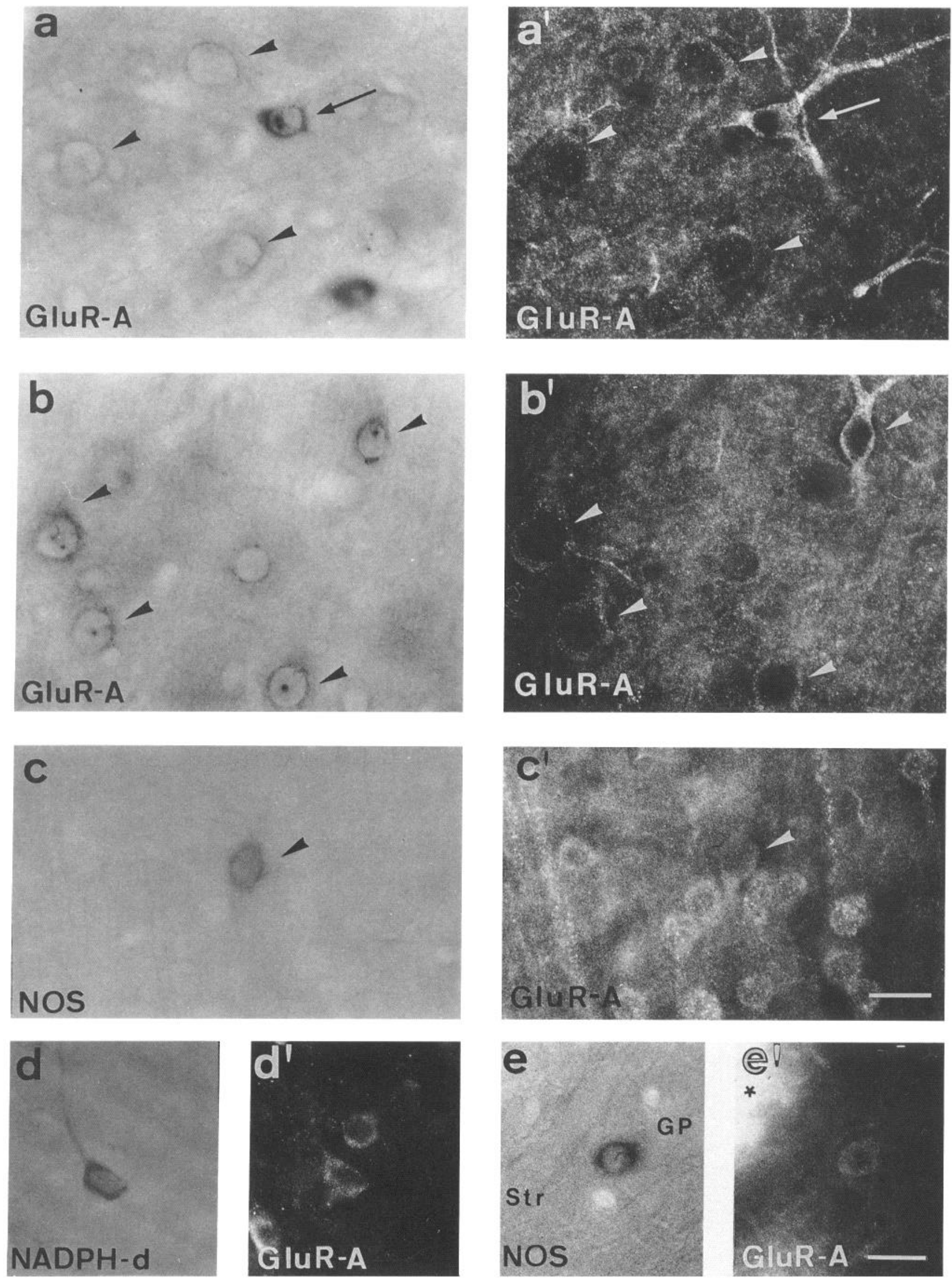
a distinct somatic immunopositivity (Fig. $8 a-a^{\prime}$ ). In the cortex, the somata of pyramidal cells in the layer $\mathrm{V}$ were strongly labeled both with the mRNA probe and GluR-B/C antibody. In the striatum, despite of the intense neuropilar immunostaining, a clear, albeit faint somatic staining was easily detected in the majority of neurons that expressed moderate levels of GluR-B mRNA. In the hippocampus, an intense immunofluorescent signal for GluR-B/C was present in the cell bodies of pyramidal cells and in those hilar neurons that were GluR-B mRNA positive. In the stratum oriens and radiatum, a colocalization of GluR-B mRNA and protein was difficult to establish. In the majority of neurons the immunofluorescent signal for GluR-B/C protein in the cell somata was not clearly distinguishable from the intense dendritic staining. In those few neurons that could be clearly analyzed a good correspondence between a weak to moderate signal for GluR-B mRNA and a weak somatic staining for GluR-B/C protein was evident.

As for GluR-B, the double-labeling experiment using the GluR-C mRNA probe and GluR-B/C antibody showed a substantial colocalization of the two signals. In the cortex, some cells that were strongly immunofluorescent did not show GluR-C in situ signal, suggesting that a small population of cells may express only GluR-B, but not GluR-C subunits. In the striatum, where the GluR-C in situ signal was low to moderate in the majority of small size neurons, the two signals were always colocalized. In the hippocampus, as expected, pyramidal cells showed a clear colocalization of mRNA and protein.

With the detection method used in this study the immunofluorescent signal by an antibody against the GluR-D subunit was strong only in the cerebellum where it was clearly detectable in the granule cell somata and in the processes of Bergmann glia. In the cortex, striatum, and hippocampus, a very faint occasional neuronal somatic staining contrasted with several clearly labeled astrocytes. In the reticular nucleus of the thalamus and occasionally in some cells of the cortex and hippocampus, a very faint GluR-D immunofluorescent signal was colocalized with a strong GluR-D mRNA signal (Fig. 8c-c').

\section{Combined NOS in situ hybridization or NADPH-diaphorase staining and AMPAK subunit immunocytochemistry}

The pattern of expression of NOS mRNA studied with the nonradioactive method was similar to that described previously (Bredt et al., 199la).

As expected from the scmiquantitative analysis of the GluR-A mRNA expression in NOS-immunopositive neurons and the correspondence between GluR-A mRNA and protein level, the majority of cortical neurons that were positive for NOS mRNA were weakly GluR-A immunopositive $(78 \%, n=88$; Fig. $7 c-$ $c^{\prime}$ ). In the hilus of the hippocampus, where a distinct somatic immunofluorescent signal was readily detectable, several NOS mRNA-positive neurons were GluR-A positive. However, in the striatum and the strata oriens and radiatum of the hippocampus it was not possible to distinguish a clear somatic GluR-A immunoreactivity of the NOS-positive neurons due to the the strong neuropilar fluorescent staining, with the exception of few cells located at the border with the globus pallidus (Fig. 7e-e'). The same results were obtained by combining NADPH-diaphorase staining and GluR-A immunohistochemistry (Fig. $7 d-$ $\left.d^{\prime}\right)$.

With the GluR-B/C antibody, which clearly labeled the cell bodies, only $8 \%(n-134)$ of NOS mRNA-containing neurons in the cortex were positive (Fig. $8 b-b^{\prime}$ ). In the striatum and hippocampus, NOS mRNA-containing neurons were never found GluR-B/C immunopositive. Analogous results were found by using NADPH-diaphorase staining as a marker of NOS-positive neurons.

When GluR-D immunohistochemistry was combined with NOS in situ hybridization or NADPH-diaphorase staining, a GluR-D-positive signal was found occasionally in a few cells of the hilar region of the hippocampus.

\section{Discussion}

The main results of these double-labeling experiments can be summarized as follows: (1) NOS-positive neurons express very low to nondetectable levels of the GluR-B subunit. (2) There is a region-dependent variability within the NOS-positive cell population, reflected in the subunit composition of their AMPARs and in the expression of the GAD-65 and -67 isoforms. (3) Good correspondence is seen between levels of AMPAR mRNAs and the respective proteins.

\section{Low levels of GluR-B subunit is a common feature of NOS positive neurons in the cortex, striatum, and hippocampus}

Our study indicates that in the analyzed brain regions the GluR-B subunit is nearly absent in NOS-expressing neurons and suggests that $\mathrm{Ca}^{2+}$ permeable AMPARs are formed in this subset of interneurons. This finding is in line with other studies in the striatum, showing that NADPH-diaphorase activity (Martin et al., 1993) and somatostatin immunoreactivity (Tallaksen-Greene and Albin, 1994) do not colocalize with GluR-B/C immunopositivity. However, low GluR-B levels are not a unique feature of NOS-positive cells. Combined molecular and functional studies have shown the presence of AMPARs with high $\mathrm{Ca}^{2+}$ permeability due to low levels of GluR-B mRNA in interneurons of the hippocampus and the visual cortex (Bochet et al., 1994; Jonas et al., 1994; Monyer et al., 1994). Furthermore, different subsets of cortical interneurons, namely parvalbumin, calbindin, and calretinin-positive neurons lack GluR-B/C immunoreactivity

$\leftarrow$

Figure 7. GluR-A in situ hybridization. NOS in situ hybridization, and NADPH diaphorase staining combined with GluR-A immunocytochemistry. For each pair of photomicrographs, the same field is shown under bright light on the left and UV light epifluorescence on the right. $a-a^{\prime}$ and $b-$ $b^{\prime}$. GluR-A in situ hybridization/GluR-A immunocytochemistry. $a$, The typical distribution pattern of GluR-A in situ hybridization signal in the cortex is shown: few scattered cells are very strongly labeled (arrow), while the majority of cells are moderately or lightly labeled (arrowheads); $a^{\prime}$ ) only those cells strongly labeled for GluR-A mRNA exhibit a strong immunofluorescent signal for GluR-A antibody (arrow), whereas the cells lightly labeled for GluR-A mRNA have a faint somatic immunofluorescent signal (arrowheads). Dendritic labeling is clearly visible only in cells containing high levels of mRNA; $b-b^{\prime}$ ) neurons containing moderate levels of in situ hybridization signal for GluR-A mRNA always show distinct GluR-A immunoreactivity (arrowheads). $c-c^{\prime}$, Representative cortical neuron positive for NOS mRNA that exhibits GluR-A immunoreactivity (arrowhead). Levels of GluR-A immunoreactivity in cortical NOS-positive neurons was never as high as in the neuron depicted in panel $a$. $d-d^{\prime}$, Representative NADPH diaphorase-positive neuron in the cortex $(d)$ that is GluR-A immunopositive $\left(d^{\prime}\right)$. $e-e^{\prime}$, A NOS mRNA-positive neuron $(e)$, located at the border between striatum $(S t r)$ and Globus pallidus $(G P)$, exhibits a faint somatic GluR-A immunofluorescent somatic staining $\left(e^{\prime}\right)$. Note the high levels of immunofluorescent signal present in the striatal neuropil (asterisk). Scale bars: $20 \mu \mathrm{m}$. 

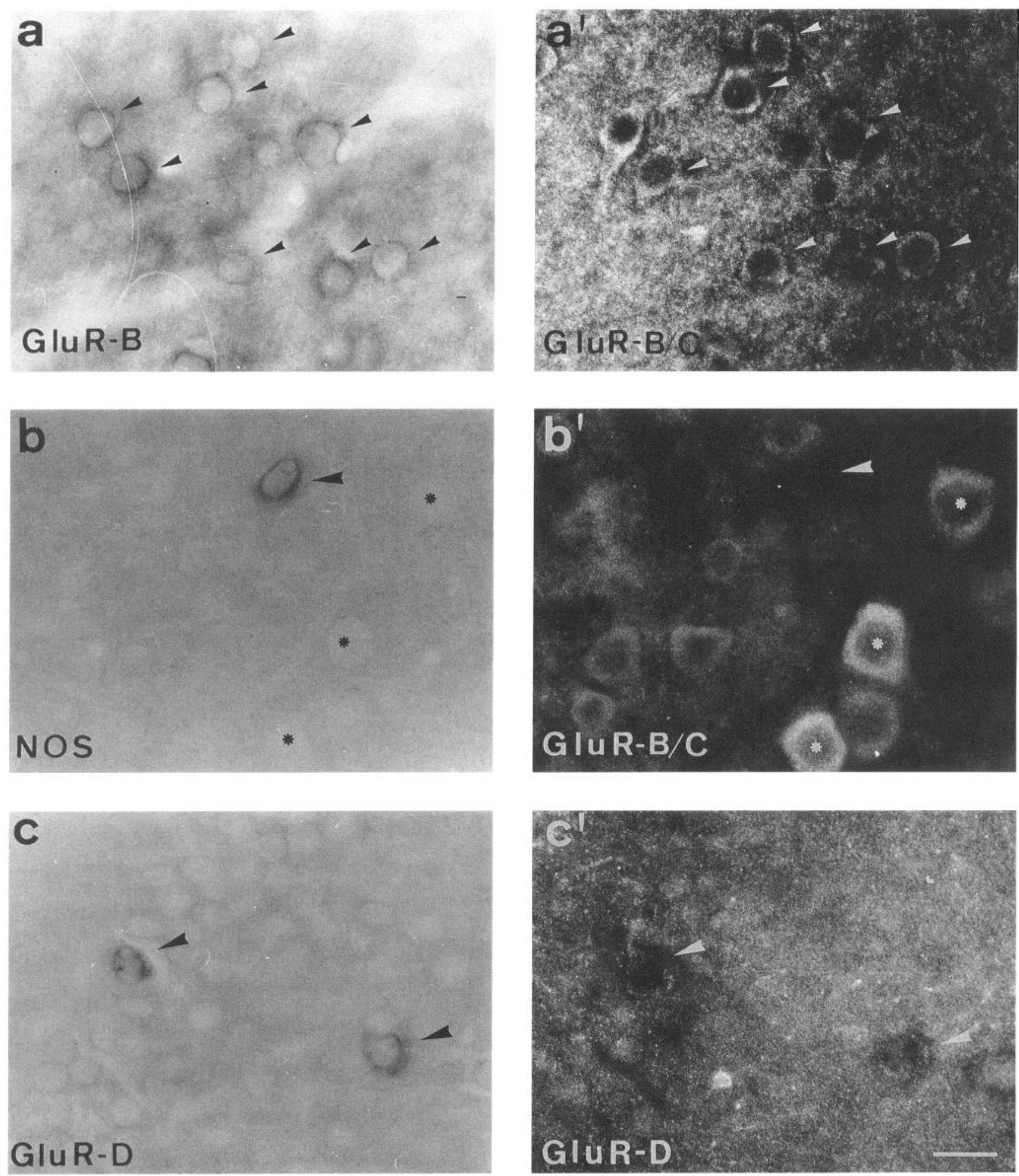

Figure 8. Double-labeling experiments combining GluR-B and NOS in situ hybridization with GluR-B/C immunocytochemistry and GluR-D in situ hybridization with GluR-D immunocytochemistry. For each pair of photomicrographs, the same field is shown under bright light on the left and UV light epifluorescence on the right. $a-a^{\prime}$, The combination of GluR-B in situ hybridization $(a)$ and GluR-B/C immunocytochemistry ( $\left.a^{\prime}\right)$ reveals a correspondence between mRNA and protein. A somatic immunofluorescent signal for GluR-B/C antibody ( $a^{\prime}$, arrowheads) is present in cortical neurons that exhibit staining for GluR-B mRNA $(a$, arrowheads $) . b-b^{\prime}$, Representative cortical neuron positive for NOS mRNA $(b)$ that does not exhibit GluR-B/C immunopositivity $\left(b^{\prime}\right)$. Several neurons in the same field are strongly (asterisks) or moderately labeled with the GluR$\mathrm{B} / \mathrm{C}$ antibody. $c-c^{\prime}$, Two putative interneurons in the stratum pyramidale and radiatum of the CAl region of the hippocampus are strongly labeled for GluR-D mRNA ( $c$, arrowheads) and exhibit a faint fluorescent signal with the GluR-D antibody ( $c^{\prime}$, arrowheads). Scale bar: $20 \mu \mathrm{m}$. 
(Martin et al., 1993; Vickers et al., 1993). Hence, low GluR-B expression appears to be a common characteristic of interneurons, which contrasts with the high levels of this subunit in principal cells.

The presence of $\mathrm{Ca}^{2+}$ permeable AMPARs in NOS-containing neurons raises the important question whether $\mathrm{Ca}^{2+}$ entry through AMPARs might be functionally coupled to NOS activation. Although NO production is generally thought to be largely dependent on NMDA receptor-mediated $\mathrm{Ca}^{2+}$ influx (Garthwaite, 1991), $\mathrm{Ca}^{2+}$ permeable AMPARs may also be involved in NOS activation in certain subsets of neurons.

\section{Regional diversity of NOS-positive neurons is reflected in the GluR-A and $-D$, and in the GAD-65/67 expression profile}

While NOS-positive neurons share the common feature of low GluR-B expression, they show a difference with regard to GluR-A and -D expression. Striatal NOS-positive cells are characterized by an overall low expression of all four subunits, the predominant subunit being GluR-A. In cortical, and particularly in hippocampal, NOS-containing neurons the preponderant subunits are GluR-A and -D. Electrophysiological data from heterologously expressed recombinant receptors suggest that the rapid desensitization of AMPA receptors is regulated by the expression and alternative splicing of GluR-D gene transcripts (Mosbacher et al., 1994). This has been confirmed by a recent study of native AMPARs in different neuronal cell types in the acute slice preparation. AMPARs with the fastest desensitization and deactivation kinetics were found on cells with high expression levels of the GluR-D subunit (Geiger et al., 1995). Thus, NOS-positive neurons in these three brain regions should differ in the kinetic properties of their AMPA receptors, due to differential regulation of GluR-D expression. Our data would predict that AMPA receptor gating properties are faster in hippocampal NOS-positive cells than in cortical and striatal ones.

Further indication for the different functional rolc of NOSpositive cells within distinct circuits in these three brain regions is provided by our finding that the two GAD isoforms exhibit a differential distribution in the NOS-positive cell population. Cortical NOS-positive cells express high levels of GAD-65 but low levels of GAD-67. In the striatum, on the other hand, both GAD isoforms are expressed at low or undetectable levels in NOSpositive cells. Yet another expression profile of GAD-65 and -67 was observed in hippocampal NOS-positive cells with variable levels for both isoforms. Low levels of both GAD isoforms were expected in the striatum based on previous studies that showed no expression of GAD mRNA (Chesselet and Robbins, 1989) and protein (Kita and Kitai, 1988) in somatostatin-containing striatal neurons. However, our finding regarding differential GAD expression in cortical NOS-positive cells were unexpected. While overall expression of GAD-67 was higher than that of GAD-65, the opposite ratio of expression levels was seen in NOS-positive neurons. The functional significance of the differential GAD isoform expression in NOS-positive cells is unclear, but it possibly reflects the different role of the two isoforms within an inhibitory circuit.

\section{AMPAR subunit expression in NOS-positive neurons is regulated at the $M R N A$ level}

Another quest of our study was to investigate whether the AMPAR mRNAs and proteins in NOS-positive cells are expressed at comparable levels. This was studied by employing different double-labeling protocols that consisted of the identification of
NOS-positive neurons by either a NOS specific cRNA or by NADPH-diaphorase staining combined with AMPAR subunitspecific immunocytochemistry. This analysis had to be limited to those regions where surrounding neuropilar staining did not preclude visualization of AMPAR immunostaining in NOS-positive cells. Hence, as expected from the in situ hybridization results, low GluR-A mRNA levels in cortical NOS-positive neurons were reflected in low protein levels in this cell population. In the striatum, the analysis could be carried out only at the border to the globus pallidus, a region lacking the uniform neuropilar staining present in the rest of the striatum. Reflecting the very low levels of of GluR-A mRNA, we detected a very faint GluR-A immunopositivity in these striatal NOS-positive neurons. Similarly in the hippocampus, the evaluation was possible only in the hilar region, indicating that the GluR-A subunit is expressed at the protein level in NOS-positive cells. These results were further supported by the general correspondence between GluR-A mRNA and its protein in other cell populations. In fact, cells characterized by high lcvels of GluR-A mRNA expression exhibited abundant levels of the corresponding protein, whereas low levels of mRNA resulted in low protein levels.

As expected from the low or undetectable GluR-B mRNA levels in NOS-positive cells, the GluR-B/C specific antibody almost never labeled these neurons. The paucity of these subunits in NOS-positive neurons contrasts with high expression in principal neurons in each of the three brain regions examined in this study.

The direct analysis of the GluR-D subunit protein in NOSpositive neurons was limited by the low levels of GluR-D immunoreactivity in the forebrain regions. When GluR-D mRNA and its protein were analyzed together, coincidence of the two signals was observed in those regions (e.g., reticulothalamic nucleus and cerebellar granular cell layer) exhibiting high levels of mRNA, suggesting different threshold sensitivity of the in situ hybridization and immunohistochemical detection methods. Hence, we found few GluR-D immunopositive NOS-containing neurons only in the hippocampus, where GluR-D mRNA levels were higher than in other regions.

The correlation between mRNA levels and protein levels found in our study indicates that mRNA levels, indeed, reflect the subunit composition of native GluR channels in an identified subset of GABAergic interneurons.

\section{AMPAR subunit distribution in NOS-positive neurons: implications for EAA-induced toxicity and neurodegenerative diseases}

$\mathrm{Ca}^{2+}$ entry through GluRs lacking GluR-B can explain the AMPA-triggered neurotoxicity observed in cultured NOS-containing neurons (Koh and Choi, 1988; Dawson et al., 1992) and the death of NOS-positive neurons after AMPA-induced striatal lesions in vivo (Beal et al., 1991). This preferential AMPA-induced cell loss is not unique for NOS-positive cells but has been demonstrated for GABAergic cells in general (Yin et al., 1994). As low GluR-B expression holds true for different GABAergic interneurons, a direct link can be proposed between $\mathrm{Ca}^{2+}$ permeable AMPARs in a small cell population and preferential destruction of these cells following exposure to AMPA. It is not clear, however, which factors detcrmine in vivo whether glutamate-induced injury is mainly NMDA or AMPA/kainate receptor mediated. It is of particular note that the enhanced AMPA susceptibility of both NOS-positive neurons and GABAergic cells is generally associated with a relative resistance to NMDA- 
induced toxicity (Koh and Choi, 1988; Tecoma and Choi, 1989; Beal et al., 1991). In fact, the reduced NMDA receptor-mediated toxicity in NOS-positive neurons may be possibly due to NMDA receptor current inactivation induced by $\mathrm{Ca}^{2+}$ influx (Mayer and Westbrook, 1987) through AMPA receptors (Medina et al., 1994). This would explain the relative resistance of NOS-positive cells to NMDA receptor-induced toxicity observed both in vitro and in vivo. Still, it is difficult to determine whether and to which extent the activation of $\mathrm{Ca}^{2+}$ permeable AMPAR channels plays a role under pathological conditions. NOS-positive neurons are generally resistant in neurodegenerative diseases, such Huntington disease (Ferrante et al., 1985) and Alzheimer disease (Hyman et al., 1992; Unger and Lange, 1992). On the other hand, a selective loss of somatostatin-containing neurons, which also express NOS (Dun et al., 1994), has been reported in patients with temporal-lobe epilepsy (Robbins et al., 1991), but other cells, namely the hilar GABAergic basket cells, which exhibit AMPA-mediated $\mathrm{Ca}^{2+}$ currents, are extremely resistant to epileptic mediated injury (Sloviter, 1987). Thus, a simple model in which a particular subunit expression profile could explain the enhanced susceptibility in a particular pathological setting cannot be made, and several additional factors contributing to exacerbate or reduce neuronal damage in different cell populations should be considered.

\section{References}

Beal MF, Ferrante RJ, Swartz. KJ, Kowall NW (1991) Chronic quinolinic acid lesions in rat closely resemble Huntington's disease. J Neurosci 11:1649-1659.

Bochet P, Audinat E, Lambolez B, Crépel F, Rossier J, Iino M, Tsuzuki K, Ozawa $S$ (1994) Subunit composition at the single-cell level explains functional properties of a glutamate-gated channel. Neuron 12: $383-388$

Bredt DS, Glatt CE, Hwang PM, Fotuhi M, Dawson TM, Snyder SH (1991a) Nitric oxide synthase protein and mRNA are discretely localized in neuronal populations of the mammalian CNS togeher with NADPH diaphorase. Neuron 7:615-624.

Bredt DS, Hwang PM, Glatt CE, Lowenstein C, Reed RR, Snyder SH (199lb) Cloned and expressed nitric oxide synthase structurally resembles cytochome P-450 reductase. Nature 351:714-718.

Burnashev N, Monyer H, Seeburg PH, Sakmann B (1992) Divalent ion permeability of AMPA receptor channels is dominated by the edited form of a single subunit. Neuron 8:189-198.

Chesselet MF, Robbins E (1989) Characterization of striatal neurons expressing high levels of glutamic acid decarboxylase messenger RNA. Brain Res 492:237-244.

Choi DW (1988) Glutamate neurotoxicity and diseases of the nervous system. Neuron 1:623-634.

Choi DW (1994) Clinical potential of AMPA/kainate receptor antagonists. Semin Neurosci 6:127-132.

Dawson VL, Dawson TM, Bartley DA, Uhl GR, Snyder SH (1993) Mechanisms of nitric oxide-mediated toxicity in primary brain cultures. J Neurosci 13:1651-1661.

Dinerman JL, Dawson TM, Schell MJ, Snowman A, Snyder SH (1994) Endothelial nitric oxide synthase localized to hippocampal pyramidal cells: implication for synaptic plasticity. Proc Natl Acad Sci USA 91: 4214-4218.

Dun NJ, Dun SL, Wong RKS, Förstermann U (1994) Colocalization of nitric oxide synthase and somatostatin immunoreactivity in rat dentate hilar neurons. Proc Natl Acad Sci USA 91:2955-2959.

Erlander MG, Tillakaratne NJK, Feldblum S, Patel N, Tobin AJ (1991) Two genes encode distinct glutamate decarboxylases. Neuron 7:91100.

Esclapez M, Tillakaratne NJK, Tobin AJ, Houser CR (1993) Comparative localization of mRNAs encoding two forms of glutamic acid decarboxylase with nonradioactive in situ hybridization methods. J Comp Neurol 331:339-162.

Ferrante RJ, Kowall NW, Beal MF, Richardson EP, Bird ED, Martin JB (1985) Selective sparing of a class of striatal neurons in Huntington's disease. Science 230:561-563.
Garthwaite J (1992) Glutamate, nitric oxide and cell-cell signalling in the nervous system. Trends Neurosci 14:60-67.

Geiger GRP, Melcher T, Jonas P, Monyer H (1995) Molecular basis of calcium permeability and kinetic properties of native AMPA receptors. In: Learning and memory, Proceedings of the 23rd Göttingen neurobiology conference (Elsner N. Menzel M, eds). New York: Thieme.

Gilbertson TA, Scobey R, Wilson (1991) Permeation of calcium ions through non-NMDA glutamate channels in retinal bipolar cells. Science 251:1613-1615.

Hedlich A, Lüth HG, Werner L, Bär B, Hanish U, Wilkelmann E (1990) GABAerge NADPH-diaphorase-positive Martinottizellen in visuellen Cortex der Ratte. J Hirnforsch 31:681-687.

Hollman M, Heinemann S (1994) Cloned glutamate receptors. Annu Rev Neurosci 17:31-108.

Hume RI, Dingledine R, Heinemann SF (1991) Identification of a site in glutamate receptor subunits that controls calcium permeability. Science 253:1028-1031.

Hyman BT, Marzloff K, Wenniger JJ, Dawson TM, Bredt DT. Snyder SH (1992) Relative sparing of nitric oxide synthase containing neurons in the hippocampal formation in Alzheimer's disease. Ann Neurol 32:818-820.

Iino M, Ozawa S, Tsuzuki K (1990) Permeation of calcium through excitatory amino acid receptor channels in cultured rat hippocampal neurons. J Physiol (Lond) 424:151-165.

Jonas P, Racca C, Sakmann B, Seeburg PH, Monyer H (1994) Differences in $\mathrm{Ca}^{2+}$ permeability of AMPA-type glutamate receptor channels in neocortical neurons caused by differential GluR-B subunit expression. Neuron 12:1281-1289.

Keinänen K, Wisden W, Sommer B, Werner P, Herb H, Verdoon TA, Sakmann B, Seeburg PH (1990) A family of AMPA-selective glutamate receptors. Science 249:556-560.

Kita H, Kitai ST (1988) Glutamate decarboxylase immunoreactive neurons in rat neostriatum: their morphological types and populations. Brain Res 447:346-352.

Koh D-S, Geiger JRP, Jonas P, Sakmann B (1995) $\mathrm{Ca}^{2+}$ permeable AMPA and NMDA receptor channels in basket cells of rat hippocampal dentate gyrus. J Physiol (Lond), in press.

Koh J, Choi D (1988) Vulnerability of cultured cortical neurons to damage by excitotoxins: differential susceptibility of neurons containing NADPH-diaphorase. J Neurosci 8:2153-2163.

Kubota Y, Mikawa S, Kawaguchi Y (1993) Neostriatal GABAergic interneurons contain NOS, calretinin or parvalbumin. Neuroreport 5:205-208.

Martin LJ, Blackstonc CD, Levey AI, Huganir RL, Price DL (1993) AMPA glutamate receptor subunits are differentially distributed in rat brain. Neuroscience 53:327-358.

Mayer ML, Westbrook GL (1987) Permeation and block of $N$-methylD-aspartic acid receptor channels by divalent cation in mouse cultured central neurons. J Physiol (Lond) 394:501-527.

Mayer ML, McDermott AB, Westbrook GL, Smith SJ, Barker JL (1987) Agonist- and voltage-gated calcium entry in cultured mouse spinal cord neurons under voltage clamp measured using arsenazo III. J Neurosci 7:3230-3244.

Mc Bain CJ, Dingledine R (1993) Heterogeneity fo synaptic glutamate receptors on $\mathrm{CA} 3$ stratum radiatum interneurons of rat hippocampus. J Physiol (Lond) 462:373-392.

Medina I, Filippova N, Barbin G, Ben-Ari Y, Bregestovski P (1994) Kainate-induced inactivation of NMDA currents via an elevation of intracellular $\mathrm{Ca}^{2+}$ in hippocampal neurons. J Neurophysiol 72:456465.

Meldrum B, Garthwaite J (1990) Excitatory amino acid neurotoxicity and neurodegenerative disease. Trends Pharmacol Sci 11:379-387.

Mercugliano M, Soghomonian J-J, Qin Y, Nguyen HQ, Feldblum S, Erlander MG, Tobin AJ, Chesselet MF (1992) Comparative distribution of messenger RNAs encoding glutamic acid decarboxylases (Mr 65,000 and $\mathrm{Mr} 67,000$ ) in the basal ganglia of the rat. J Comp Neurol 318:245-254.

Monyer H, Melcher T, Seeburg PH, Geiger J, Sakmann B, Jonas P (1994) Different ratios of subunit expression critically determinc calcium permeability and kinetics of the AMPA receptors in the CNS. Soc Neurosci Abstr 20:96.4.

Moriyoshi K, Masu M, Ishii T, Shigemoto R, Mizuno N, Nakanishi S (1991) Molecular cloning and characterization of the rat NMDA receptor. Nature $354: 31-37$. 
Mosbacher J, Schoepfer R, Monyer H, Burnashev N, Seeburg PH, Ruppersberg JP (1994) A molecular determinant for submillisecond desensitization in glutamate receptors. Science 266:1059-1062.

Petralia RS, Wenthold RJ (1992) Light and electron immunocytochemical localization of AMPA-selective glutamate receptors in the rat brain. J Comp Neurol 318:329-354.

Robbins RJ, Brines ML, Kim JH, Adrian T, deLanerolle N, Welsh S, Spencer DD (1991) A selctive loss of somatostatin in the hippocampus of patients with temporal lobe epilepsy. Ann Neurol 29:325-332.

Sato K, Kiyama H, Tohyama M (1993) The differential expression patterns of messenger RNAs encoding non- $N$-methyl-D-aspartate glutamate receptor subunits (GluR $1-4$ ) in the rat brain. Neurosciencc 52: $515-539$.

Sloviter RS (1987) Decreased hippocampal inhibition and a selective loss of interneurons in experimental epilepsy. Science 235:73-76.

Sommer B, Keinänen K, Verdoon TA, Wisden W, Burnashev N, Herb A, Köhler M, Takagi T, Sakmann B, Seeburg PH (1990) Flip and flop: a cell specific functional switch in glutamate-operated channels of the CNS. Science 249:1580-1585.

Tallaksen-Greene S, Albin R (1994) Localization of AMPA-selective excitatory amino acid receptor subunits in identified populations of striatal neurons. Neuroscience 61:509-519.

Tecoma ES, Choi DW (1989) GABAergic neocortical neurons are resistant to NMDA receptor-mediated injury. Neurology 39:676-682.

Unger JW, Lange W (1992) NADPH-diaphorase-positive cell populations in the human amygdala and temporal cortex: neuroanatomy, peptidergic characteristic and aspects of aging and Alzheimer's disease. Acta Neuropathol 83:636-646.
Valtschanoff JG, Weinberg RJ, Kharazia VN, Schmidt IIIIIIW, Nakane M, Rustioni A (1993) Neurons in rat cerebral cortex that synthesize nitric oxide: NADPH diaphorase histochemistry, NOS immunocytochemistry, and colocalization with GABA. Neurosci Lett 157:157161.

Valtschanoff JG, Weinberg RJ, Kharazia VN, Nakane M, Schmidt HHHW (1993) Neurons in rat hippocampus that synthesize nitric oxide. J Comp Neurol 331:111-121.

Vickers JC, Huntley GW, Edwards AM, Moran T, Rogers SW, Heinemann SF, Morrison JH (1993) Quantitative localization of AMPA/ kainate glutamate receptor subunit immunoreactivity in neurochemically identified subpopulations of neurons in the prefrontal cortex of the macaque monkey. J Neurosci 13:2982-2992.

Wahle P, Beckh S (1992) A method of in situ hybridization combined with immunocytochemistry, histochemistry, and tract tracing to characterized the mRNA expressing cell types in heterogeneous neuronal populations. J Neurosci Methods 41:153-166.

Weiss JH, Turetsky D, Wilke G, Choi D (1994) AMPA/kainate receptor-mediated damage to NADPH-diaphorase containing neurons is $\mathrm{Ca}^{2+}$ dependent. Neurosci Lett 167:93-96.

Wenthold RJ, Yokotani N, Doi K, Wada K (1992) Inımunochennical characterization of the non-NMDA glutamate receptor using subunitspecific antibodies. J Biol Chem 267:501-507.

Wyborski RJ, Bond RW, Goettlieb DI (1990) Characterization of a cDNA coding for a rat glutamic acid decarboxylase. Mol Brain Res 8:193-198.

Yin H-Z, Turetsky D, Choi DW, Weiss JH (1994) Cortical neurons with $\mathrm{Ca}^{2+}$ permeable AMPA/kainate channels display distinct receptor immunoreactivity and are GABAergic. Neurobiol Dis 1:43-49. 